\title{
Fishing Ground Mapping Model in The Semi-Enclosed Saleh Bay, West Nusa Tenggara
}

\author{
Anang Dwi Purwanto ${ }^{1,}$, Ulung Jantama Wisha ${ }^{2}$, Erick Karno Hutomo ${ }^{3}$ \\ ${ }^{1}$ Remote Sensing Applications Center, LAPAN \\ ${ }^{2}$ Research Institute for Coastal Resources and Vulnerability, Ministry of Marine Affairs and \\ Fisheries \\ ${ }^{3}$ Faculty of Fisheries and Marine Science, Diponegoro University, Indonesia \\ *) Corresponding Author (e-mail: anang.dwi@lapan.go.id)
}

Received: 05 August 2020 / Accepted: 24 June 2021 / Published: 31 July 2021

\begin{abstract}
Saleh Bay is a semi-enclosed area of water in Nusa Tenggara Barat Province that is enriched by fisheries resources. The bay's strategic position, surrounded by several small islands, makes it an area of fertile water. An area of water is considered a potentially ideal fishing ground if it contains several oceanographic phenomena, including thermal fronts and upwelling. Fishing activities in Saleh Bay have been found to be ineffective and inefficient due to local people's continued use of traditional methods such as fishing by signs of nature (instincts), wind direction, astrological signs and previous experience. This study aimed to create a mapping model of the fishing grounds in Saleh Bay based on remote sensing satellite data. Spatial analysis of daily level 3 images from the Suomi-National PolarOrbiting Partnership (SNPP) was conducted throughout January and August 2019. The image acquisition period was adapted based on the seasonal system of Indonesia. The study area was determined based on thermal front events as identified by sea surface temperature (SST) data analysed using statistical regression with a Non-Linear Multi-Channel SST (NLSST) approach. An ideal fishing ground is characterised by several oceanographic settings such as upwelling and thermal front occurrence. The average SST distribution in January 2019 was relatively high, ranging from 30.39 to $33.70^{\circ} \mathrm{C}$, while in August 2019, the temperature declined significantly, ranging from 25.09 to $29.30^{\circ} \mathrm{C}$. Concerning the fishing ground model, a plethora of potential fishing ground areas were identified in August compared to January 2019, at 144 and 42 points respectively. This reflected the density of the fishing grounds observed. The fishing grounds were most likely to be concentrated in the bay mouth during the southwest monsoon and within the bay near the plateau during the northeast monsoon. The seasonal variability of Saleh Bay played a significant role in the spatial extraction of the fishing ground data.
\end{abstract}

Keywords: Fishing Ground, Thermal Front, Density, SNPP-VIIRS, Saleh Bay

\section{Introduction}

Indonesia has abundant capture fisheries resources that reflect the national scale of the economic sector within this archipelagic country. However, Indonesia's strategic position means it has become the centre of international shipping lanes for the maritime industry, as prioritised by Indonesia's government (Maradong, 2016). According to Indonesian Fisheries Law No. 45, 2009, fisheries are activities related to the management and utilisation of fishery resources. In the context of fishery business systems, these activities range from pre- 
production, production and processing to marketing. A previous study stated that Indonesian fisheries used only around 4.1 million tonnes/year $(63.5 \%)$ out of a total potential of 6.4 million tonnes/year (Utami et al., 2012). This indicates that the fishery sector remains far from achieving its full potential. Saleh Bay, West Nusa Tenggara is one potential area with a precious fishery resource.

Saleh Bay is directly bordered by the Flores Sea in the north and contains various natural resources. Surrounded by small islands, the bay is a very fertile area of West Nusa Tenggara Province and is well known for its fishery potential. The primary fishery commodities are grouper (Epinephelus sp.), snapper (Lutjanus sp.), mackerel tuna (Auxis thazard), flying fish (Decapterus macrosomia) and mackerel (Scomberomorus commersonii). The location of a fishing ground needs to be well determined in order to support and maximise the catching of fish. The application of Geographic Information System (GIS) and remote sensing data can help in determining fishing grounds in Saleh Bay. In this case, remote temperature data are a significant indicator of potential fishing grounds, thus enabling fishing activity to become more effective and efficient.

In an archipelago region containing a vast area of water, choosing the best method for monitoring ocean conditions is essential to the ability to accurately predict fishing grounds. Remote sensing technology and GIS can be used to solve this issue. The remote sensing method enables the acquisition of data and information relating to an object without any direct interaction (Lillesand \& Kiefer, 2015). Moreover, remote sensing technology can be applied quickly, efficiently and with sufficient accuracy (Rokhmana, 2012). It is not possible to monitor the resources of a very extensive area of water in a conventional manner. However, it is possible to use remote sensing satellite image data with low resolution due to its wide spatial coverage, supported by daily temporal resolution capabilities. This can make the monitoring of water area resources more effective and efficient and can save costs.
Several previously published studies have used satellite data to predict fishing grounds. Arief et al. (2015) developed a temperature extraction model of surface waters using Landsat 8 satellite imagery. In contrast, Arif et al. (2018) applied Landsat 8 OLI imagery to zone fishing ground potential in the waters of Wakatobi. Wibisana et al. (2018) developed an optimal mathematical model of sea surface temperature in the northern coastal area of Gresik, Indonesia, based on the reflectance values of Aqua MODIS satellite imagery. Suwargana et al. (2010) also developed fishing ground prediction models using sea surface temperature and chlorophyll-a data from Aqua MODIS imagery satellite. Overall, however, prior studies have only detected fishing grounds by employing commonly used satellite imagery data. In this study, we employed sea surface temperature data extracted from SNPPVIIRS imagery, which is the most up-to-date high-resolution satellite technology. It yields better quality results than the low-resolution images used by the foregoing studies (LAPAN, 2014). To date, there have been no reports regarding fishing ground predictions within Saleh Bay. A previous survey in Saleh Bay by Yulius et al. (2015) sought to determine the water quality within the bay. Later, Heriati et al. (2017) analysed and modelled oceanographic parameters such as tidal, currents and waves. A study investigating fishing ground potential is essential to support local fishers in their fishing activities. This study aimed to create a mapping model of fishing grounds in the semienclosed water area based on the emergence of a thermal front as extracted from the sea surface temperature data. The resulting model is expected to help traditional fishers increase their current catches of fish.

\section{Research Method}

\subsection{Study Area Overview}

The study area was situated in Saleh Bay, West Nusa Tenggara and positioned between $8^{\circ} 2^{\prime} 41.79^{\prime \prime}-8^{\circ} 45^{\prime} 49.71^{\prime \prime}$ South and $117^{\circ} 29^{\prime} 53.39^{\prime \prime}$ - $118^{\circ} 22^{\prime} 26.47^{\prime \prime}$ East. The archipelago region of West Nusa Tenggara Province comprises 
various small islands surrounded by the Indian Ocean. As a semi-enclosed area of water, Saleh Bay is a frequent target for fishing. The study area is shown in Figure 1. Saleh Bay is linked to the Flores Sea, surrounded by Sumbawa and semi-enclosed by Mojo Island. Consequently, as a water region, it is sufficiently fertile due to its intake of land-sourced organic and inorganic materials. Moreover, the oceanographic state of Saleh Bay tends to erratic. The bottom substrate ecosystem consists of corals, rubble, seagrass and sand. As a result, valuable demersal fish are dominant. The types of demersal fish commonly captured by locals include mackerel tuna (Euthynnus affinis), skipjack (Katsuwonus pelamis), mackerel (Scomberomorus sp.), various squid (Loligo $\mathrm{sp}$. ), flying fish (Decapterus sp.), Rastrelliger brachysoma, sardine fish (Sardinella sp.) and grouper (Epinephelus sp.) (Edrus \& Suprapto, 2013).

\subsection{Data Acquisition}

The data used in this study comprised sea surface temperatures extracted from daily SNPP-VIIRS level 3 imagery retrieved from the web page modis-catalog.lapan.go.id. We saved the downloaded data in the VSSTCO and GMTCO formats. The employed data were recorded over two observation periods of one month each, covering 1-31 January 2019 and 1-31 August 2019. Remote sensing software played an essential role in amalgamating VIIRS-NPP satellite images, determining the coordinate positions, converting images and performing the layouting stages.

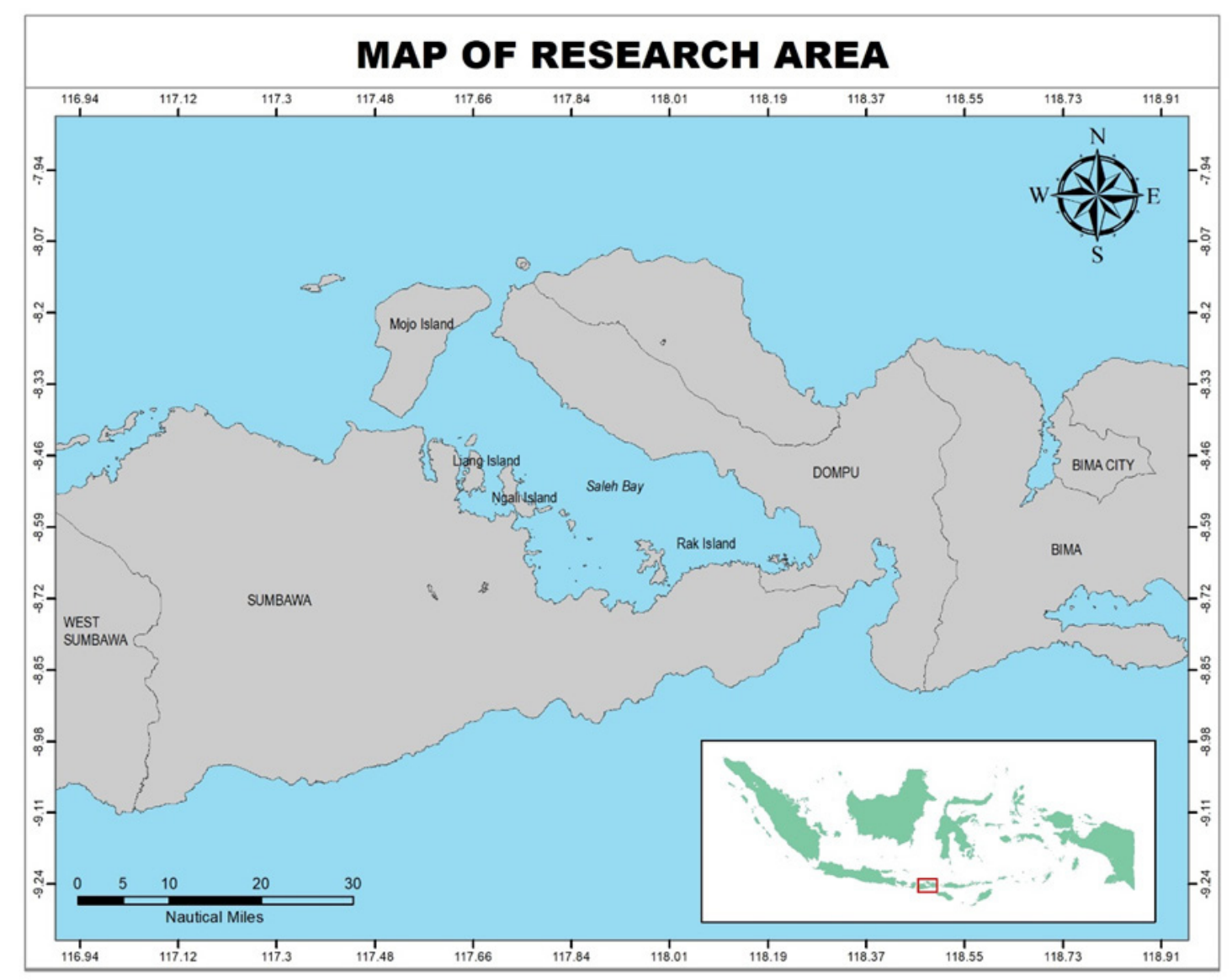

Figure 1. Map of the study area. 


\subsection{Sea Surface Temperature Data} Extraction

The initial process involved converting sea surface temperature data from the NetCDF (.nc) to the GeoTIFF format and cropping the image to reflect the study location of Saleh Bay using Seadas 7.5.1 software. The SST algorithm for SNPP-VIIRS images was based on statistical regression using a Non-Linear Multi-Channel SST (NLSST) approach (Table 1). The algorithm was adapted from Walton (1988) listed on VIIRS-SST ATBD 2011 (LAPAN, 2015), with the following equation:

$$
\begin{aligned}
& \operatorname{SST}_{d t}=a_{0}+a_{1} T_{11}+a_{2}\left(T_{11}-T_{12}\right) \text { RSST }+a_{3} \\
& \left(T_{11}-T_{12}\right)(\sec (z)-1)
\end{aligned}
$$

where:

$\begin{array}{lrl}S S T_{d t}= & \begin{array}{l}\text { Sea Surface Temperature at } \\ \text { midday }\end{array} \\ a_{0^{\prime}} a_{1^{\prime}} a_{2^{\prime}} a_{3}= & \text { Coefficient value obtained from } \\ & \text { regression analysis } \\ = & \text { Brightness temperature at } 11 \mu \mathrm{m} \\ \mathrm{T}_{11} & \text { (VIIRS M15 channel) } \\ = & \text { Brightness temperature at } 12 \mu \mathrm{m} \\ & \text { (VIIRS M16 channel) } \\ \mathrm{T}_{12} & = \\ \mathrm{RSST} & \text { The first SST value prediction } \\ & \text { based on the National Centers for } \\ & \text { Environmental Prediction } \\ \mathrm{Z} & \text { Zenith angle sensor }\end{array}$

Table 1. Regression analysis coefficients for NLSST.

\begin{tabular}{ccc}
\hline Coefficient & $\left.\mathbf{( T}_{\mathbf{1 1}}-\mathrm{T}_{\mathbf{1 2}}\right)<\mathbf{0 . 7} \mathrm{K}$ & $\left.\mathbf{( T}_{\mathbf{1 1}}-\mathrm{T}_{\mathbf{1 2}}\right)>\mathbf{0 . 7} \mathrm{K}$ \\
\hline$a_{0}$ & 1.228552 & 1.692521 \\
$a_{1}$ & 0.9576555 & 0.95558419 \\
$a_{2}$ & 0.1182196 & 0.0873754 \\
$a_{3}$ & 1.774631 & 1.199584 \\
\hline
\end{tabular}

\subsection{Point Determination of Fishing Grounds}

Before determining the potential zone for fishing grounds, it was necessary to identify the emergence of thermal fronts using the Single Image Edge Detection (SIED) method as referenced from Cayula and Cornillon (1992). A thermal front is a confluence of water masses with different temperatures (Hanintyo et al., 2015). The SIED workflow uses a sea surface temperature threshold value of $0.5 \mathrm{oC}$ to detect a thermal front from a distance of 1-3 kilometres (Hasyim, 2015; Marpaung et al., 2017). This process was corroborated by Simbolon et al. (2013), who stated that the availability of indicators supporting the existence of fish could help in determining a potential fishing ground. These indicators comprise water fertility as reflected by chlorophyll-a and the existence of a thermal front and upwelling as elicited from SST distribution. All of the fishing ground points and densities were analysed using point counting techniques in a polygon. The polygon vector used was a grid measuring 0.0625 degrees in size, with the scope of this grid adjusted to the map scale at the study site.

The point counting results were then classified based on the total points in a grid. Figure 2 contains a flowchart depicting the stages of the fishing ground analysis.

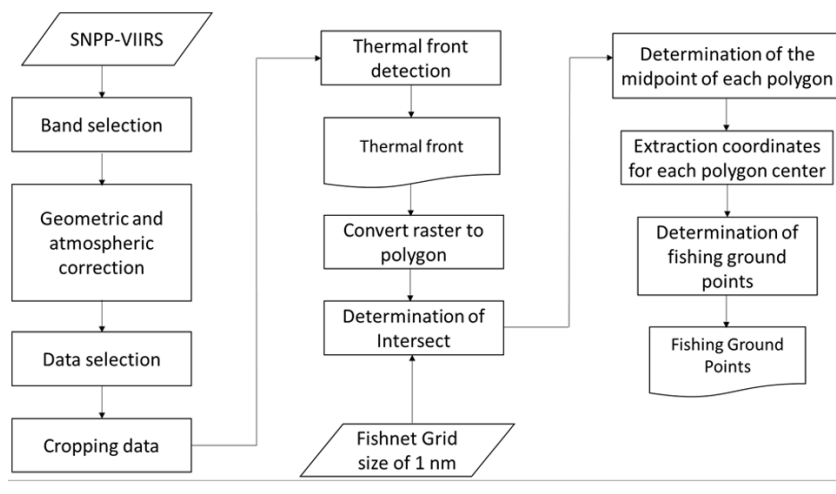

Figure 2. Flowchart of the fishing ground analysis.

3. Results and Discussion

3.1. Fishing Ground Information

The SNPP-VIIRS level 3 image extraction yielded a total of 31 data points each month. However, only several of these could be analysed; the remaining SST data were not representative of the study area due to the high cloud coverage. According to the data extraction, the lowest thermal front SST of January 2019 was identified on 9 January, 
positioned at $117^{\circ} 43^{\prime} 37.2^{\prime \prime} \mathrm{E}-8^{\circ} 26^{\prime} 9.6^{\prime \prime} \mathrm{S}$ with a temperature of $30.39{ }^{\circ} \mathrm{C}$. While the lowest thermal front SST of August 2019 was identified on 25 August, positioned at $117,833 \mathrm{E}-8,479 \mathrm{~S}$ with a temperature of $25.09{ }^{\circ} \mathrm{C}$. The highest thermal front SST of January 2019 was found on 8 January at $117^{\circ} 51^{\prime} 10.8^{\prime \prime} \mathrm{E}-8^{\circ} 29^{\prime} 20.4^{\prime \prime} \mathrm{S}$ with 33.33 ${ }^{\circ} \mathrm{C}$. While the highest thermal front SST of August 2019 was identified on 12 August at 117.621 E - 8,364 S with $29.17^{\circ} \mathrm{C}$. According to Aisyah et al. (2018), the temperature of Saleh Bay ranged from 30.8 to $32.3{ }^{\circ} \mathrm{C}$. Mujiyanto and Wasilun (2006) explained that in the southeast monsoon period (June-August), sea surface temperature declined in Saleh Bay to around $27^{\circ} \mathrm{C}$. The temperature values obtained by those previous studies do not differ significantly from those determined by this study. Figure 3 contains an example of an SST extraction result and the SST contours in Saleh Bay.

In January 2019, the thermal front was identified at five-day of observation, while for August 2019, the thermal front was observed in 14-day separately. Thus, it was simpler to conduct the fishing ground estimation during the southwest monsoon when the images were not frequently obscured by cloud.

There were only five data points in January 2019 that we were able to map into potential fishing ground information, namely on $8,9,10,14$ and 20 January (Figure 4 ). We had a total of 42 fishing ground data points for January 2019, with 8 January producing the most information for the month, at 18 data points. Fewer points were obtained on 14 and 20 January due to reduced identification of thermal front indicators. It was not possible to process the remaining 26 data points for the January recording period due to cloud coverage in the study area. Where data could be detected, several points were recorded beyond the study area.

August 2019 yielded a greater amount of fishing ground information compared to January 2019. A total of 135 points were generated in August 2019, on 1, 6-9, 11, 12, 14, 16, 19, 23, 25, 27 and 28 August (Figure 4). August 12 yielded the highest number of observations, at 41 points. An interpreter was then required to assist in processing the fishing ground information. Figure 4 shows a comparison of the fishing ground information obtained during January and August 2019.

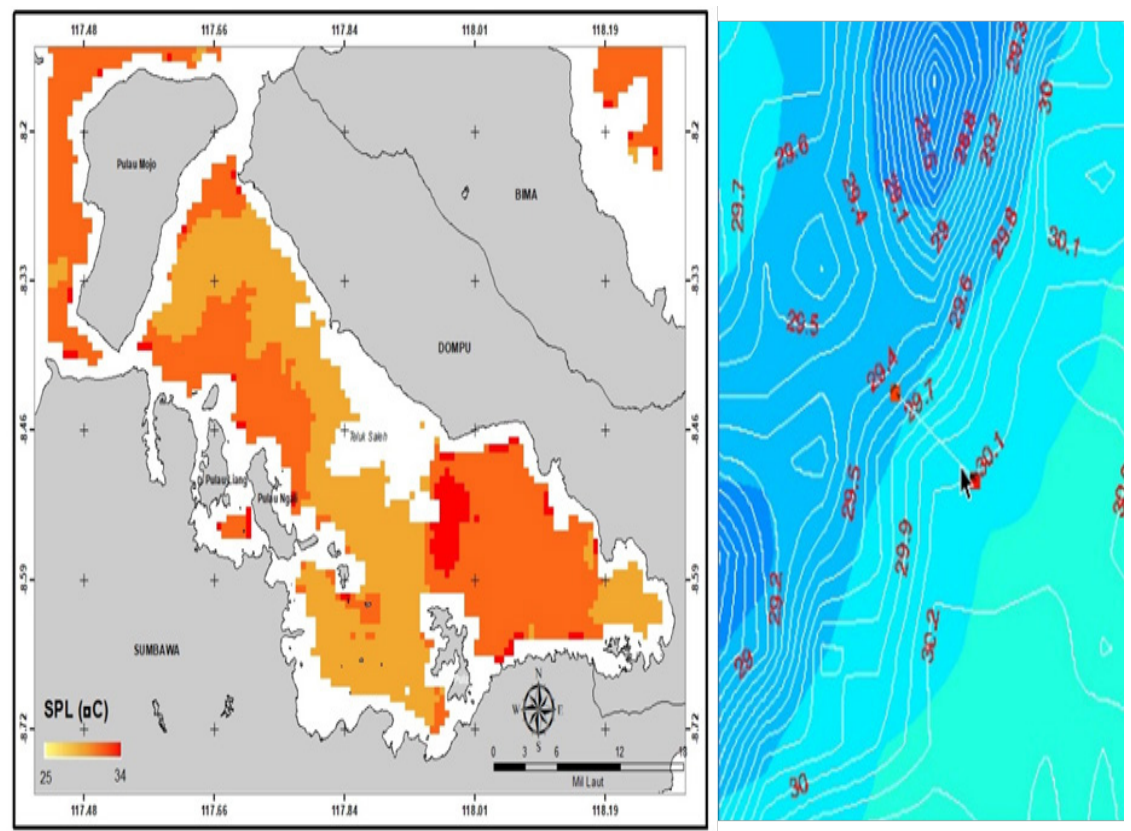

Figure 3. Example of SST extraction result. 

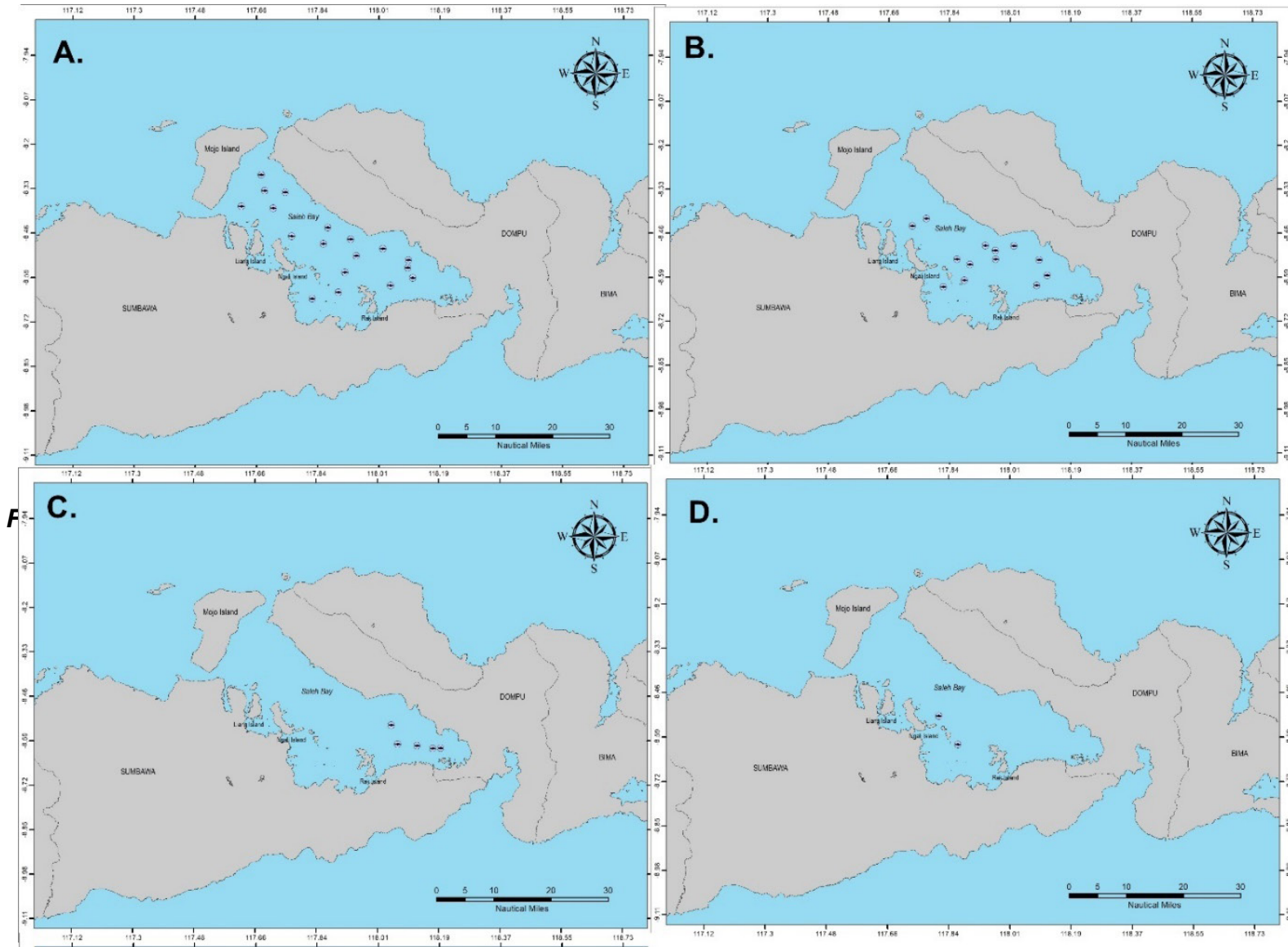

D.

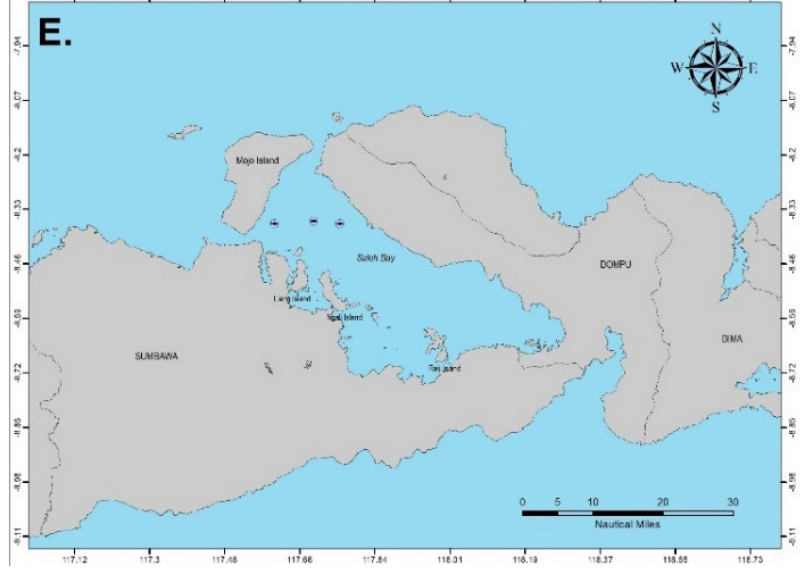

Legend:

$\hookrightarrow$ Potential Fishing Ground

Source:

1. Analysis of SNPP-VIIRS Image

2. Administrative Boundary Map

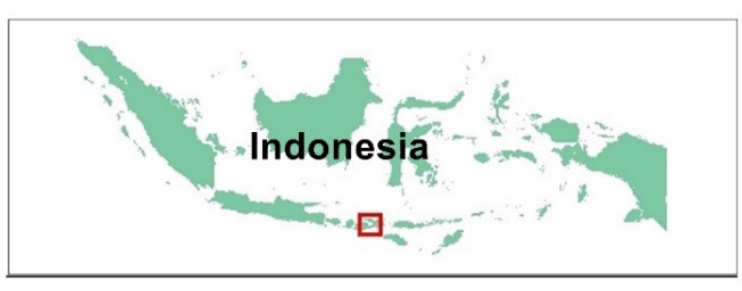

Figure 5. Map of potential fishing grounds in Saleh Bay during the January 2019 observation; A. 8 Jan. 2019, B. 9 Jan. 2019, C. 10 Jan. 2019, D. 14 Jan. 2019, E. 20 Jan. 2019.

Figure 5 displays the fishing ground information obtained during January 2019. A relatively high number of fishing ground points were observed on 8-9 January compared to the other dates analysed. For the month as a whole, the fishing ground potential in Saleh Bay was fairly erratic. However, several fishing ground areas were identified in the northern Plampang and Empang sub-districts. As observed, on 8 January, the potential fishing ground points were very widely scattered throughout Saleh Bay. Five points were identified in the bay mouth, ten within the bay and three near the coast and small islands in the bay. The day after the first observation, the data showed a decline in the number of fishing ground points, with no grounds that had previously been observed in the bay mouth. We only observed fishing ground potential centred within the bay, with a total of 13 data points. The remainder of 
the data acquired in January 2019 showed a downward trend, which tended to be erratic, with only between two and five locations identified within the bay and near the coastal area.

Figure 6 contains an amalgamation of the points observed during January 2019 while Table 2 contains a list of their coordinates. It was expected that predicting fishing ground points based on thermal front indicators would be a suitable method. The surface temperature of Saleh Bay in January 2019 was likely to be stable due to the low movement of the water mass within the semi-enclosed bay. This created suitable conditions for certain species and led to the bay becoming tremendously rich and fertile, supporting biota metabolism and the number of fish catching. According to Cahya et al. (2016), physical, biological and chemical parameters are factors in supporting the water ecosystem. In contrast, temperature and other physical factors are the most straightforward parameters to observe. In reality, these environmental parameters will influence the distribution, migration, aggregation, reproduction, food availability and behaviour of water biota.

As observed during August 2019, we obtained more daily data because the satellite images were clearer compared to January 2019. The fishing ground points detected during this period are shown in Figure 7 . The points began moving from the mouth of the bay on 1 August, propagating towards the bay on 7 August. A very large number of fishing grounds were then observed during the second week of August. The densest points were detected on 12 August 2019, with as many as 38 separate points within Saleh Bay (Figure 7G).

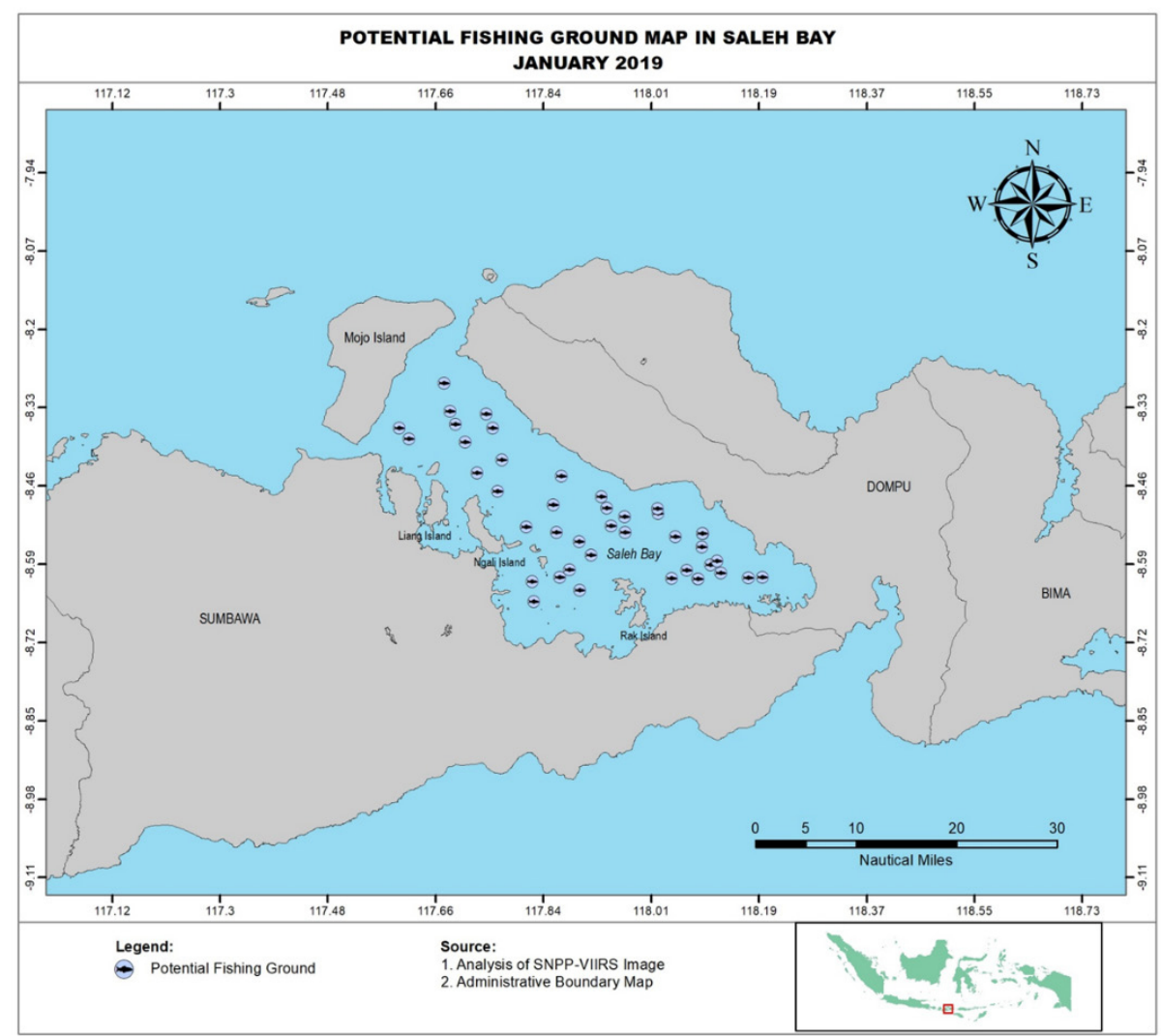

Figure 6. Amalgamated fishing ground points in Saleh Bay during January 2019. 
Table 2. Coordinates of fishing grounds in January 2019.

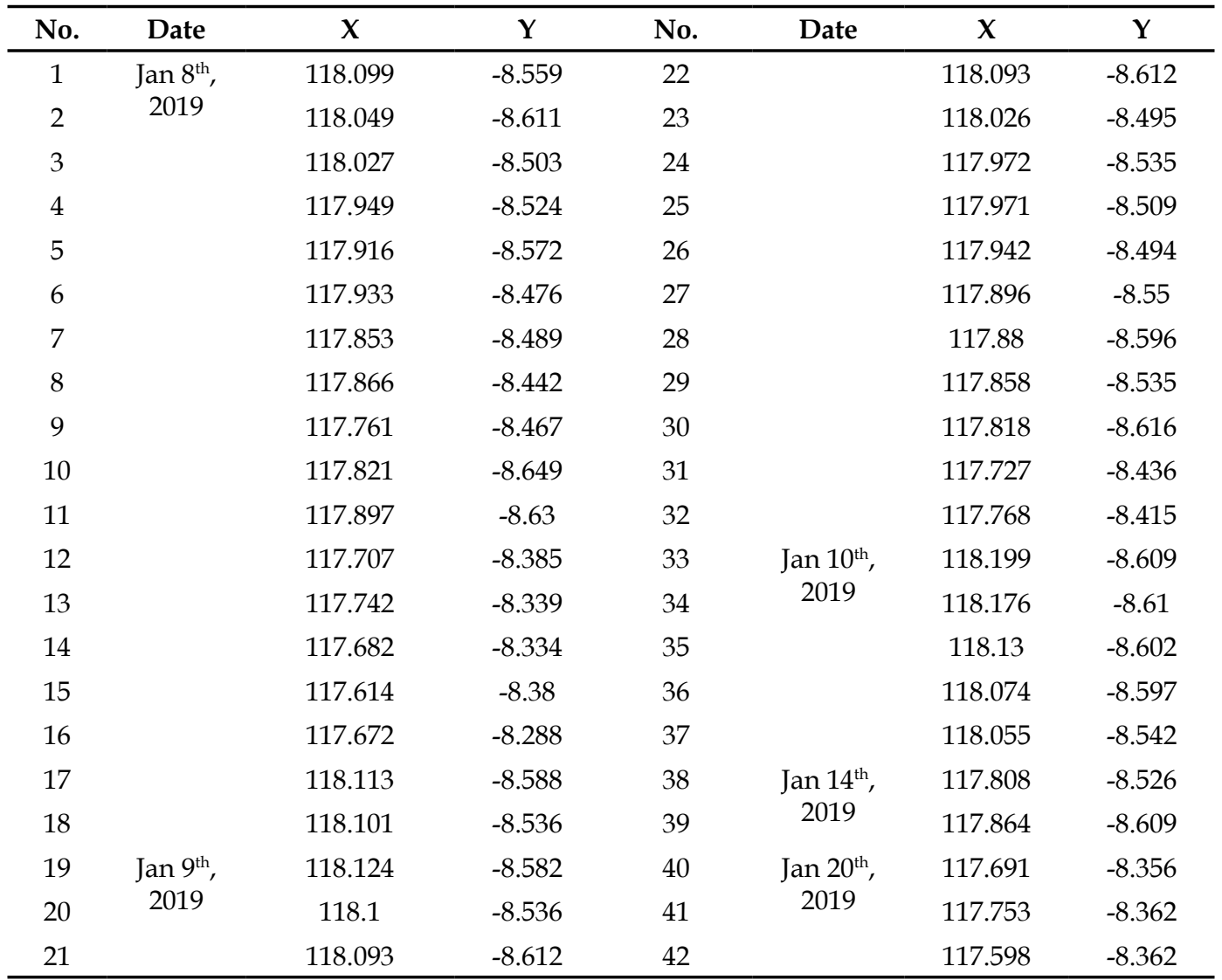

In contrast, the day after this peak, the number of locations detected fell dramatically, with only six points identified (Figure 7F). The fewest points were identified on 19 and 25 August, when only two points were identified within the bay. The rest of the data show the same pattern of fishing ground propagation, centralised in the bay mouth. The coordinates of the fishing ground points in August 2019 are given in Table 3.

The aggregated fishing ground points identified during August 2019 are shown in Figure 8. Overall, the denser points were identified in the bay mouth and near Mojo Island, in line with the possible existence of a coral reef ecosystem. Moving towards the mainland, there is a gradual reduction in the number of fishing grounds. This demonstrates the dominant role of oceanography parameters in inducing local transport and upwelling. Overall, Saleh Bay has the potential to become a key capture fisheries resource.
This study's main indication was obtained using temperature distribution; as such, the circulation of wave-driven currents is significant to control the temperature distribution within a semi-enclosed bay. To determine the distribution of fishing ground points detected by the SNPP-VIIRS satellite imagery, we employed wave simulations from the previous study by Heriati et al. (2017) (Figure 9). According to those simulations, waves propagated predominantly towards the bay during the northeast monsoon and in the opposite direction during the southwest monsoon. Southeasterly waves moved towards the bay mouth at the same height of around 1.5 metres, which relates to the prediction of the fishing ground indicators detected in this study. In January 2019 (northeast monsoon), following northwesterly waves that induced movement in a landward direction, a concentration of fishing ground points was detected within the bay near 
Dompu and the Sumbawa plateau. This is wherein the southeasterly waves induced a why the SST-indicated upwelling was most low-temperature water mass to move towards likely to follow the same pattern as the wave the bay mouth, leading to much greater propagation. The opposite applied in the case potential for fishing grounds in the bay mouth of the southwest monsoon (August 2019), and near Mojo Island.

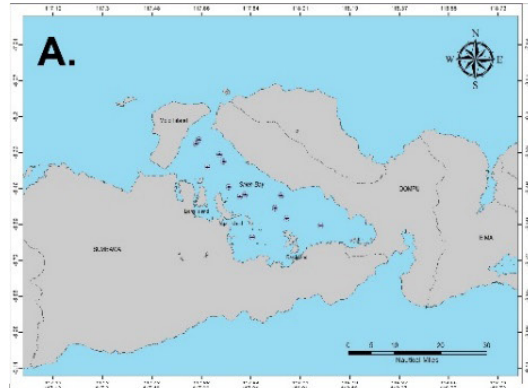

B.

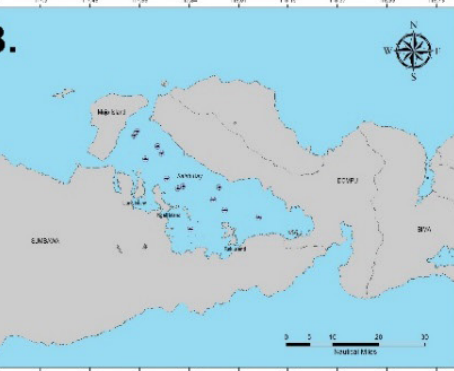

D.

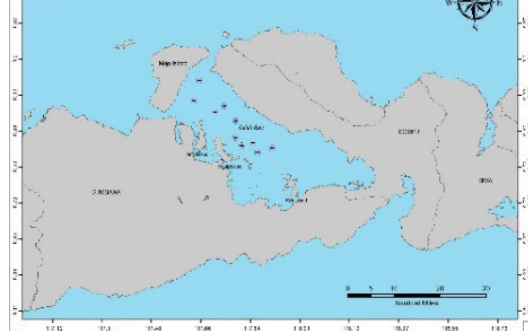

G.
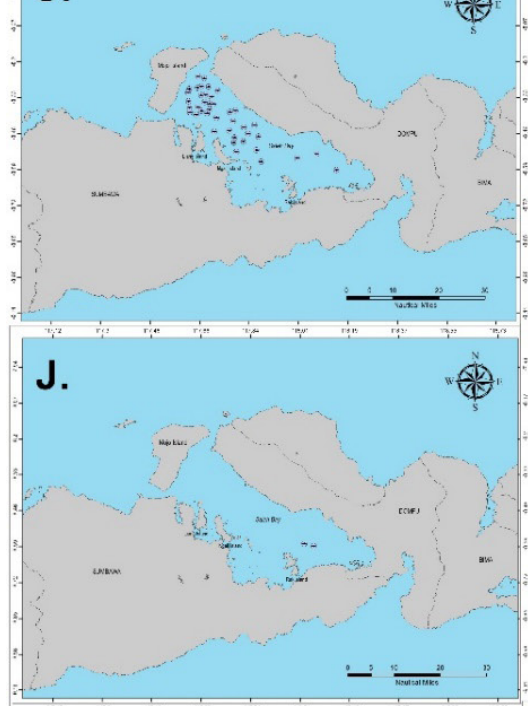

M.

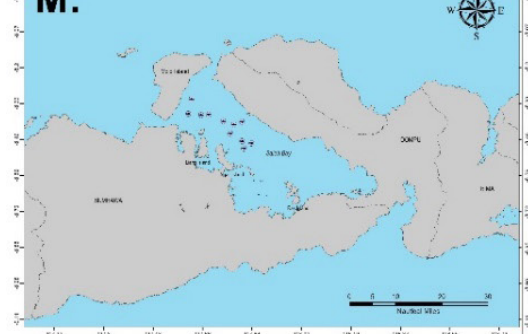

E.

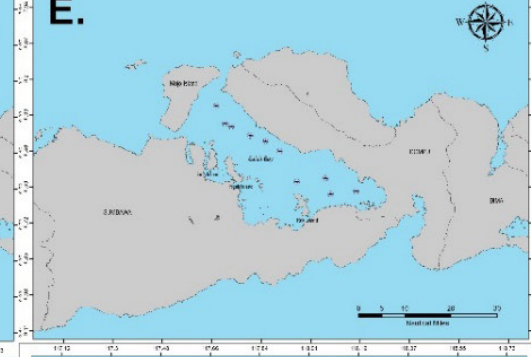

H.

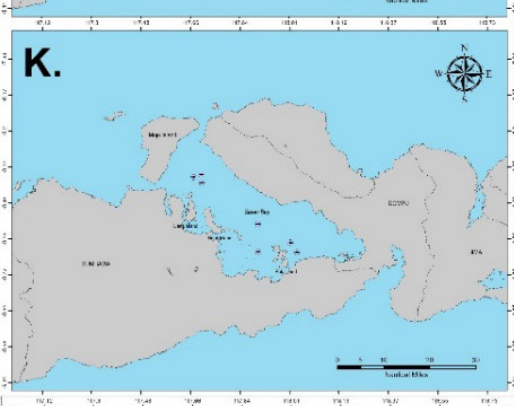

$\mathbf{N}$.

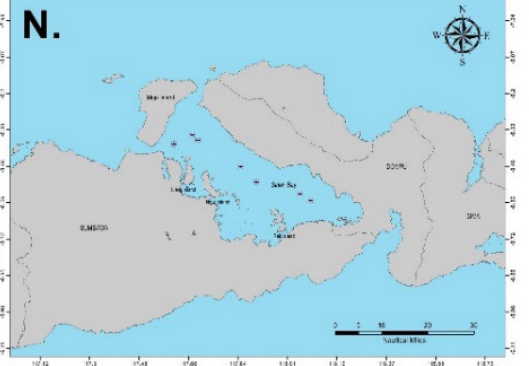

C.
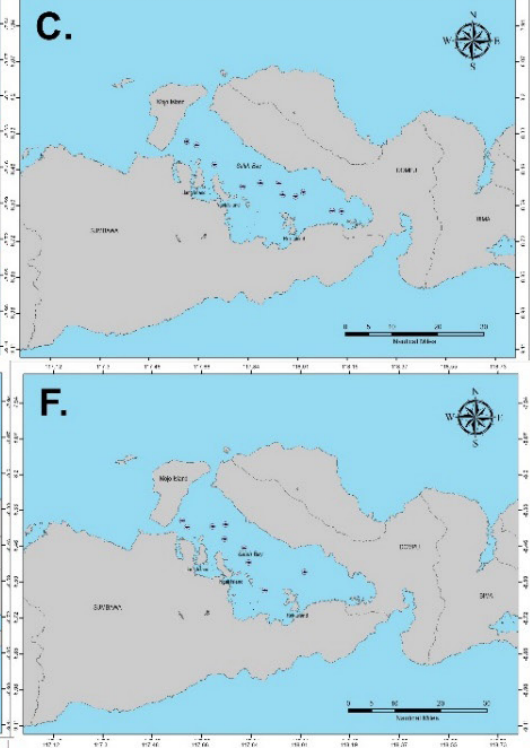

I.
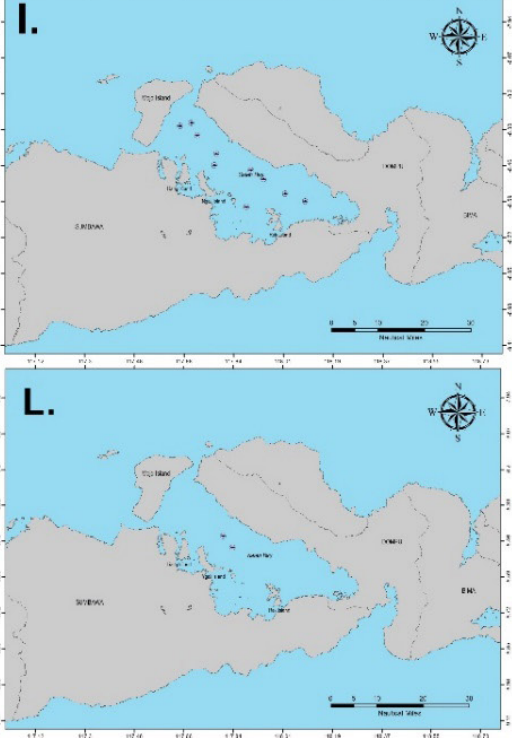

Legend:

- Potential Fishing Ground

Source:
1. Analysis of SNPP-VIIRS Image

2. Administrative Boundary Map

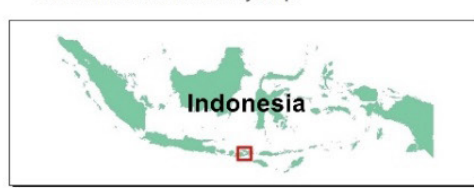

Figure 7. Map of potential fishing grounds in Saleh Bay during August 2019; A. 1 Aug. 2019; B. 6 Aug. 2019; C. 7 Aug. 2019; D. 8 Aug. 2019; E. 9 Aug. 2019; F. 11 Aug. 2019; G. 12 Aug. 2019; H. 14 Aug. 2019; I. 16 Aug. 2019; J. 19 Aug. 2019; K. 23 Aug. 2019; L. 25 Aug. 2019; M. 27 Aug. 2019; and N. 28 Aug. 2019. 


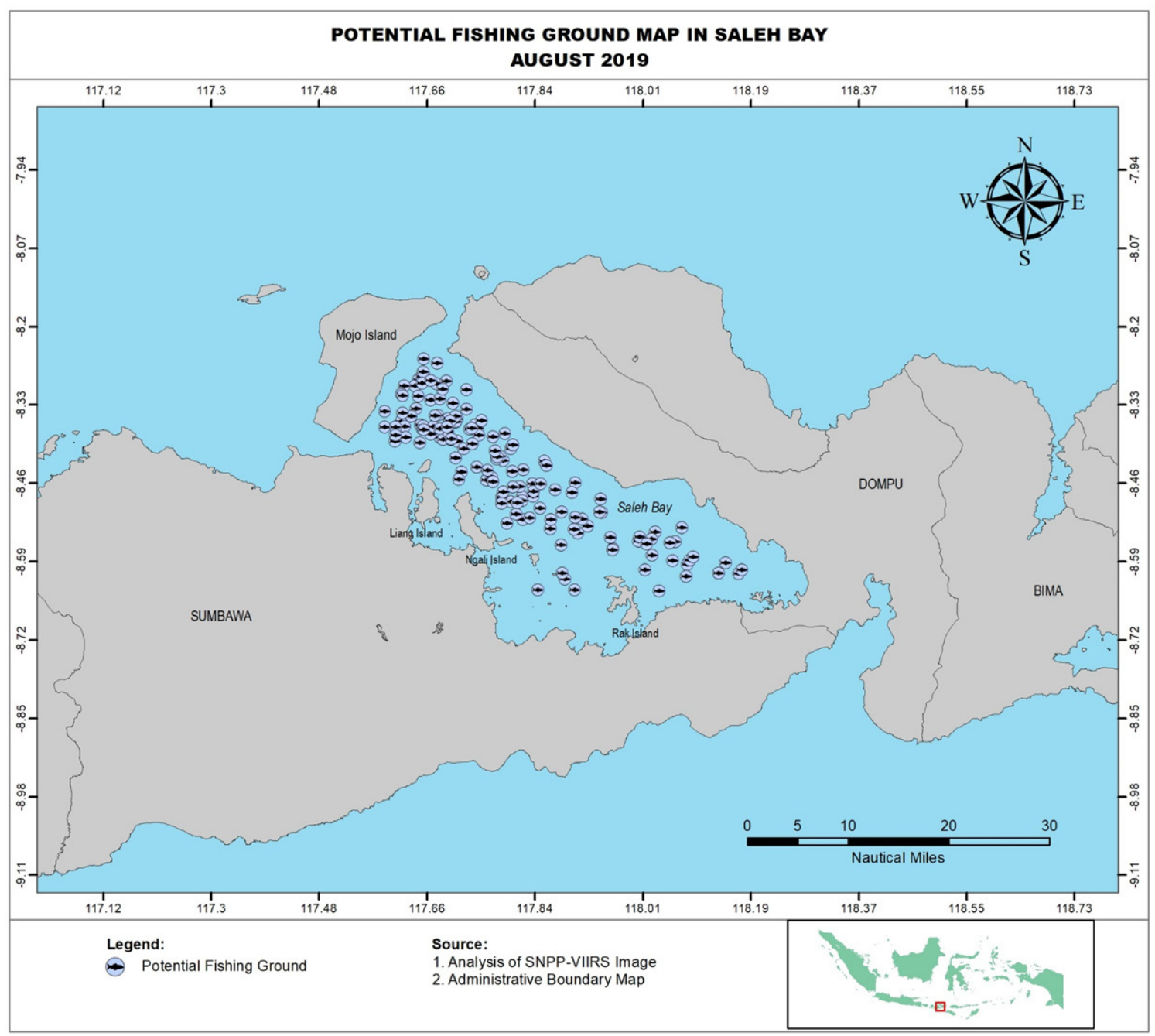

Figure 8. Amalgamated fishing grounds in Saleh Bay during August 2019.

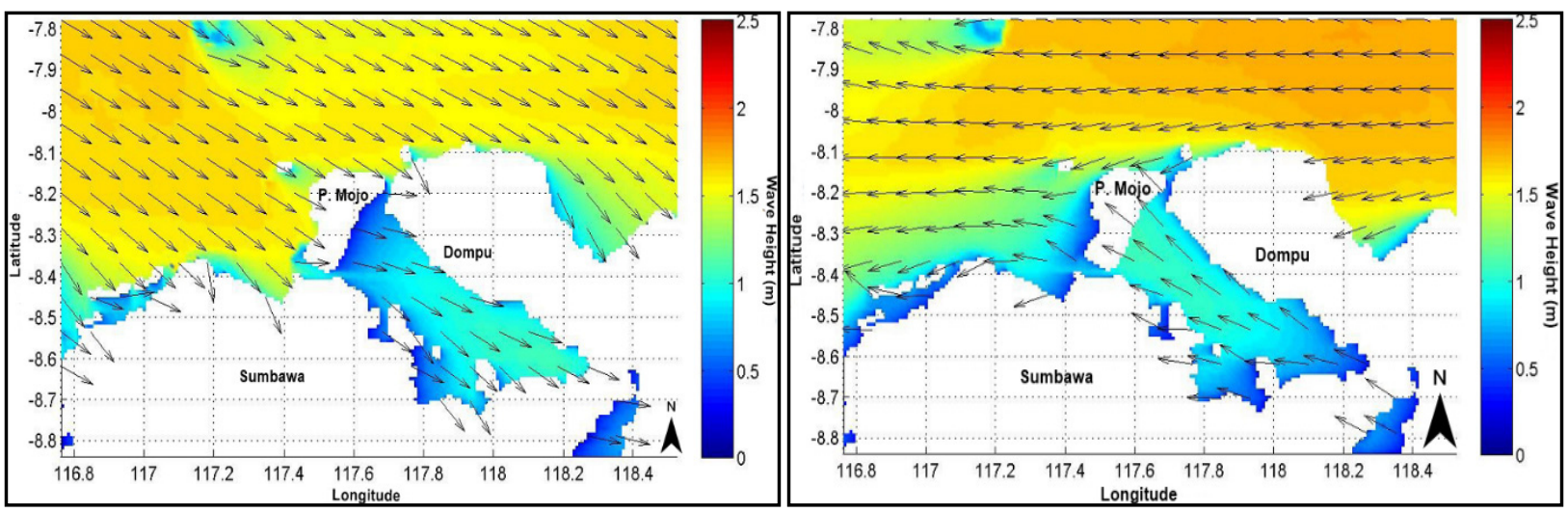

Figure 9. Wave simulation in Saleh Bay during northeast (top) and southwest (bottom) monsoons Source: Heriati et al. (2017), modified by the author. 
Table 3. Coordinates of fishing grounds in August 2019.

\begin{tabular}{|c|c|c|c|c|c|c|c|c|c|c|c|}
\hline No. & Date & $X$ & $Y$ & No. & Date & $X$ & $\mathbf{Y}$ & No. & Date & $X$ & $\mathbf{Y}$ \\
\hline 1 & Aug $1^{\text {st }}$ & 117.588 & -8.338 & 46 & \multirow{5}{*}{$\begin{array}{l}\text { Aug } \\
11^{\text {th }}, \\
2019\end{array}$} & 118.087 & -8.612 & 91 & \multirow{8}{*}{$\begin{array}{l}\text { Aug } \\
14^{\text {th }}, \\
2019\end{array}$} & 117.863 & -8.518 \\
\hline 2 & 2019 & 117.647 & -8.361 & 47 & & 118.179 & -8.601 & 92 & & 117.88 & -8.56 \\
\hline 3 & & 117.644 & -8.287 & 48 & & 117.588 & -8.365 & 93 & & 118.01 & -8.546 \\
\hline 4 & & 117.64 & -8.334 & 49 & & 117.605 & -8.388 & 94 & & 118.079 & -8.531 \\
\hline 5 & & 117.654 & -8.28 & 50 & & 117.697 & -8.385 & 95 & & 118.152 & -8.589 \\
\hline 6 & \multirow{13}{*}{$\begin{array}{c}\operatorname{Aug} 6^{\text {th }} \\
2019\end{array}$} & 117.638 & -8.297 & 51 & \multirow{13}{*}{$\begin{array}{l}\text { Aug } \\
12^{\text {th }}, \\
2019\end{array}$} & 117.74 & -8.431 & 96 & & 117.705 & -8.356 \\
\hline 7 & & 117.649 & -8.281 & 52 & & 117.744 & -8.378 & 97 & & 117.732 & -8.366 \\
\hline 8 & & 117.723 & -8.335 & 53 & & 117.811 & -8.463 & 98 & & 117.748 & -8.354 \\
\hline 9 & & 117.738 & -8.361 & 54 & & 117.828 & -8.515 & 99 & \multirow{10}{*}{$\begin{array}{l}\text { Aug } \\
16^{\text {th }}, \\
2019\end{array}$} & 117.705 & -8.416 \\
\hline 10 & & 117.679 & -8.382 & 55 & & 117.886 & -8.616 & 100 & & 117.773 & -8.417 \\
\hline 11 & & 117.756 & -8.452 & 56 & & 118.029 & -8.55 & 101 & & 117.908 & -8.54 \\
\hline 12 & & 117.797 & -8.488 & 57 & & 117.653 & -8.252 & 102 & & 117.644 & -8.314 \\
\hline 13 & & 117.815 & -8.48 & 58 & & 117.65 & -8.292 & 103 & & 117.684 & -8.302 \\
\hline 14 & & 117.945 & -8.484 & 59 & & 117.62 & -8.297 & 104 & & 117.705 & -8.347 \\
\hline 15 & & 117.924 & -8.528 & 60 & & 117.616 & -8.31 & 105 & & 117.774 & -8.414 \\
\hline 16 & & 117.966 & -8.566 & 61 & & 117.618 & -8.341 & 106 & & 117.767 & -8.455 \\
\hline 17 & & 118.088 & -8.592 & 62 & & 117.621 & -8.364 & 107 & & 117.898 & -8.473 \\
\hline 18 & & 117.841 & -8.634 & 63 & & 117.623 & -8.382 & 108 & & 117.943 & -8.505 \\
\hline 19 & \multirow{11}{*}{$\begin{array}{c}\text { Aug } 7^{\text {th }} \\
2019\end{array}$} & 117.615 & -8.356 & 64 & & 117.652 & -8.363 & 109 & \multirow{5}{*}{$\begin{array}{l}\text { Aug } \\
19^{\text {th }} \\
2019\end{array}$} & 117.882 & -8.606 \\
\hline 20 & & 117.651 & -8.368 & 65 & & 117.664 & -8.32 & 110 & & 118.021 & -8.558 \\
\hline 21 & & 117.715 & -8.439 & 66 & & 117.664 & -8.288 & 111 & & 118.093 & -8.585 \\
\hline 22 & & 117.816 & -8.518 & 67 & & 117.675 & -8.259 & 112 & & 118.064 & -8.586 \\
\hline 23 & & 117.881 & -8.505 & 68 & & 117.69 & -8.289 & 113 & & 118.03 & -8.577 \\
\hline 24 & & 117.947 & -8.506 & 69 & & 117.679 & -8.318 & 114 & \multirow{6}{*}{$\begin{array}{l}\text { Aug } \\
23^{\text {th }} \\
2019\end{array}$} & 117.669 & -8.364 \\
\hline 25 & & 117.961 & -8.547 & 70 & & 117.676 & -8.345 & 115 & & 117.696 & -8.355 \\
\hline 26 & & 118.008 & -8.553 & 71 & & 117.664 & -8.376 & 116 & & 117.698 & -8.384 \\
\hline 27 & & 118.036 & -8.538 & 72 & & 117.646 & -8.391 & 117 & & 117.901 & -8.534 \\
\hline 28 & & 118.14 & -8.606 & 73 & & 117.685 & -8.385 & 118 & & 117.902 & -8.634 \\
\hline 29 & & 118.173 & -8.607 & 74 & & 117.693 & -8.372 & 119 & & 118.019 & -8.601 \\
\hline 30 & \multirow{10}{*}{$\begin{array}{c}\operatorname{Aug} 8^{\text {th }} \\
2019\end{array}$} & 117.632 & -8.347 & 75 & & 117.694 & -8.35 & 120 & \multirow{3}{*}{$\begin{array}{l}\text { Aug } \\
25^{\text {th }}, \\
2019\end{array}$} & 118.042 & -8.636 \\
\hline 31 & & 117.652 & -8.273 & 76 & & 117.701 & -8.325 & 121 & & 117.799 & -8.438 \\
\hline 32 & & 117.708 & -8.388 & 77 & & 117.723 & -8.303 & 122 & & 117.833 & -8.479 \\
\hline 33 & & 117.742 & -8.366 & 78 & & 117.708 & -8.351 & 123 & \multirow{7}{*}{$\begin{array}{l}\text { Aug } \\
27^{\text {th }}, \\
2019\end{array}$} & 117.618 & -8.313 \\
\hline 34 & & 117.784 & -8.42 & 79 & & 117.719 & -8.4 & 124 & & 117.653 & -8.369 \\
\hline 35 & & 117.781 & -8.481 & 80 & & 117.711 & -8.451 & 125 & & 117.606 & -8.365 \\
\hline 36 & & 117.806 & -8.509 & 81 & & 117.767 & -8.381 & 126 & & 117.679 & -8.367 \\
\hline 37 & & 117.845 & -8.499 & 82 & & 117.787 & -8.375 & 127 & & 117.733 & -8.392 \\
\hline 38 & & 117.862 & -8.533 & 83 & & 117.779 & -8.413 & 128 & & 117.758 & -8.436 \\
\hline 39 & & 117.915 & -8.517 & 84 & & 117.765 & -8.448 & 129 & & 117.771 & -8.404 \\
\hline 40 & \multirow{6}{*}{$\begin{array}{c}\text { Aug } 9^{\text {th }}, \\
2019\end{array}$} & 117.674 & -8.293 & 85 & & 117.784 & -8.472 & 130 & \multirow{6}{*}{$\begin{array}{l}\text { Aug } \\
28^{\text {th }}, \\
2019\end{array}$} & 117.807 & -8.49 \\
\hline 41 & & 117.705 & -8.357 & 86 & & 117.781 & -8.491 & 131 & & 117.834 & -8.471 \\
\hline 42 & & 117.729 & -8.368 & 87 & & 117.832 & -8.459 & 132 & & 117.606 & -8.378 \\
\hline 43 & & 117.797 & -8.4 & 88 & & 117.817 & -8.435 & 133 & & 117.671 & -8.346 \\
\hline 44 & & 117.965 & -8.568 & 89 & & 117.856 & -8.428 & 134 & & 117.691 & -8.365 \\
\hline 45 & & 118.069 & -8.554 & 90 & & 117.87 & -8.468 & 135 & & 117.846 & -8.459 \\
\hline
\end{tabular}




\subsection{Fishing Ground Density Prediction}

Figure 10 displays predictions of the fishing ground densities during the study's two observation periods. The densities are depicted on a grid measuring $0.0625 \times 0.0625$ degrees (around $250 \times 250$ metres) since this was the maximum grid size for the study area. Fish densities were grouped based on the total fishing ground points for each grid, ranging from 0 to 18 points, with a high density represented by a reddish colour. Higher densities were more likely to be found during August 2019 (Figure 10B) compared to January 2019 (Figure 10A). The relatively high fishing ground densities in August 2019 were located right around the mouth of Saleh Bay. Here, there is a possible circulation of water mass from the Banda Sea, which would enhance water fertility.

In August 2019, the wind blew predominantly from Australia to the Asian continent and this affected wave generation. Heriati et al. (2017), in their study regarding wave model simulation, explained that during southwest monsoons, southeasterly waves moved towards Saleh Bay, the propagation of which led to wave-driven currents bringing nutrient-containing sediment to certain protected areas with high biodiversity. Edrus et al. (2017) stated that Saleh Bay was a perfect habitat for coral reefs and coral reef fish. Thus, it is clear that the initial prediction regarding the high density of the detected fishing grounds in August 2019 was potentially linked to coral reef areas.

Nurfiarani et al. (2006) stated that fishers mainly carried out their fishing activities inSaleh Bay during the southwest monsoons, working at the same times every day for six months (from 18.00 to the morning). This study also shows that one of the fishing areas around Sumbawa Besar Water is in Saleh Bay, specifically around Mojo Island. Purnamaningtyas et al. (2006) also identified that fish catching in Saleh Bay peaked during the southwest season (MayAugust), totalling approximately $15-20 \mathrm{~kg} /$ month. These previous studies confirm the result of this study, whereby greater catching potential was observed during the southwest monsoon, concentrated near Mojo Island.

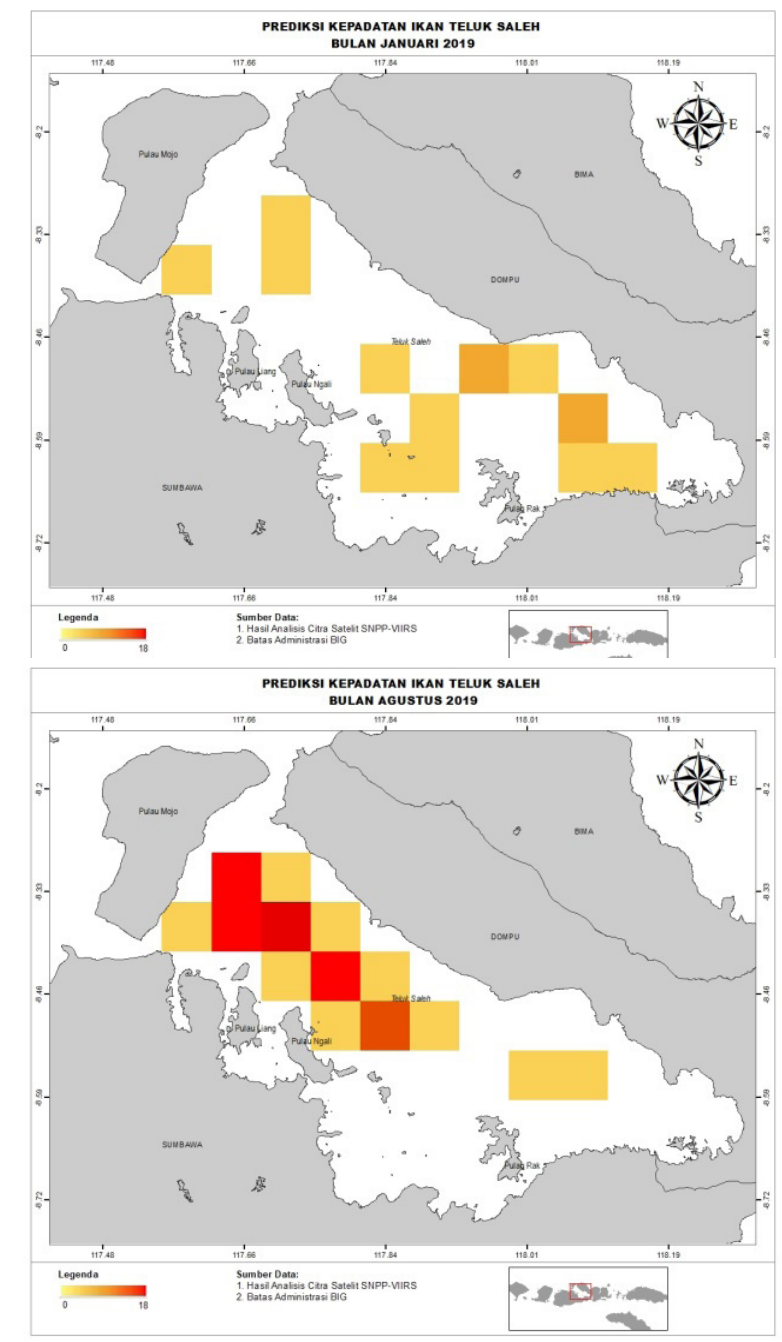

Figure 10. Density prediction of fishing grounds detected in Saleh Bay during January 2019 (top) and August 2019 (bottom).

\section{Conclusion}

Natural obstacles aside, SNPP-VIIRS satellite imagery can be employed to extract sea surface temperature data for use in determining fishing ground point information in semi-enclosed waters such as those found in Saleh Bay. More fishing ground points were identified during the August 2019 than the January 2019 observation period. The fish density levels were relatively high within the bay and near the Saleh Bay mouth (close to Mojo Island). This area sits at the centre of current circulations, creating more dynamic oceanographic features compared to other areas 
of Saleh Bay. Seasonal conditions within the bay significantly affect the quantity and quality of the fishing ground points detected using remote sensing satellite image data.

\section{Acknowledgement}

Acknowledgement and gratitude are given to the Remote Sensing Application
Center of LAPAN for providing facilities during this research, to the Remote Sensing Technology and Data Center of LAPAN for providing access to the SNPP-VIIRS satellite data, and to those who helped in the completion of this work. The main contributor of this article is Anang Dwi Purwanto.

\section{References}

Aisyah, A., Prihantono, J., \& Gunawan, D. (2018). Kajian Kualitas Perairan Untuk Budidaya Laut Di Teluk Saleh, Kabupaten Dompu. Jurnal Segara, 14(1), 57-68.

Arief, M., Adawiah, S. W., Parwati, E., Hamzah, R., \& Prayogo, T. (2015). Pengembangan Model Ekstraksi Suhu Permukaan Laut Menggunakan Data Satelit Landsat 8 Studi Kasus: Teluk Lampung (Development Model of Sea Surface Temperature Extraction Using Landsat-8 Satellite Data, Case Study: Lampung Bay). Jurnal Penginderaan Jauh dan Pengolahan Data Citra Digital, 12(2).

Arif, H., Saleh, F., \& Jaya, G. (2018). Utilization of Landsat 8 OLI / TIRS Imagery for Determining the Potential Fishing Zones in Wakatobi Regency Waters. Jurnal Geografi Aplikasi Dan Teknologi. 2(2):2018.

Cahya, D. S., \& Surinati, D. (2016). The Influence of Oceanographic Parameters on Fish Distribution. Oseana, 41(4), 1-14.

Cayula, J. F., \& Cornillon, P. (1992). Edge detection algorithm for SST images. Journal of atmospheric and oceanic technology, 9(1), 67-80.

Edrus, I. N., Arief, S., \& Setyawan, E. (2017). Kondisi kesehatan terumbu karang Teluk Saleh, Sumbawa: Tinjauan aspek substrat dasar terumbu dan keanekaragaman ikan karang. Jurnal Penelitian Perikanan Indonesia, 16(2), 147-161.

Edrus, I. N., \& Suprapto, S. (2013). Arah Kebijakan Pengembangan Perikanan Tangkap Di Sekitar Teluk Saleh, Nusa Tenggara Barat. Jurnal Kebijakan Perikanan Indonesia, 5(1), 25-38.

Hanintyo, R., Hadianti, S., \& Mahardhika, R. M. P. (2015). Aldino, \& Islamy, F. (2015). Seasonal Distribution of Thermal Front Events Based on Aqua-MODIS Imagery in WPP-RI 714, 715, WPP-RI 716. In Prosiding Seminar Nasional Penginderaan Jauh Nasional.

Hasyim, B. (2015). Pengembangan dan Penerapan Informasi Spasial dan Temporal Zona Potensi Penangkapan Ikan Berdasarkan Data Penginderaan Jauh.

Heriati, A., Mustikasari, E., \& Zahara, R. I. (2017). Karakteristik Pasang Surut Dan Gelombang Di Perairan Teluk Saleh, Nusa Tenggara Barat. Jurnal Segara, 13(1).

Lillesand, T., Kiefer, R. W., \& Chipman, J. (2015). Remote sensing and image interpretation. John Wiley \& Sons.

Maradong, D.S. (2016). High Potential of Indonesian Capture Fisheries. (https://setkab.go.id/ potensi-besar-perikanan-tangkap-indonesia).

Marpaung, S., Hamzah, R., Prayogo, T., Parwati, E., Adawiah, S. W., \& Arief, M. (2017). Analisis Informasi Zona Potensi Penangkapan Ikan (ZPPI) Harian di Perairan Laut Indonesia dan Sekitarnya The Analysis Information of Daily Potential Fishing Zones (PFZ) in Sea Waters 
of Indonesia and Surroundings.

Mujiyanto \& Wasilun. (2006). Kondisi Oseanografi di Perairan Teluk Saleh Nusa Tenggara Barta. Proceedings of Seminar Nasional Ikan IV: 217 - 229.

Nurfiarini, A., \& Widarmanto, N. (2006). Status Usaha Perikanan Tangkap di Zona Calon Rehabilitasi Terumbu Karang Pulau Rakit dan Pulau Ganteng Teluk Saleh Kabupaten Sumbawa Besar.

Purnamaningtyas, S. E., Sugianti, Y., \& Hartati, S. T. (2006). Hasil Tangkapan Ikan dengan Menggunakan Bubu di Teluk Saleh, Nusa Tenggara Barat. Proceedings of National Fisheries Seminar IV. Jatiluhur.

Pusat Pemanfaatan Penginderaan Jauh LAPAN. (2014). Pengembangan Model Pemanfaatan Data Satelit NPP dan Altimetri Untuk Penentuan Zona Potensi Penangkapan Ikan. Buku Laporan Akhir Kegiatan 2014. Jakarta.

Pusat Pemanfaatan Penginderaan Jauh LAPAN. (2015). Litbang Pemanfaatan Data Penginderaan Jauh Untuk Informasi Zona Potensi Penangkapan Ikan (ZPPI). Buku Laporan Akhir Kegiatan 2015. Jakarta.

Rokhmana, C. A. (2015). Potensi Pemanfaatan Penginderaan Jauh Dengan Wahana Udara NirAwak Di Industri Tambang Dan Migas. In Seminar Nasional Informatika (SEMNASIF) (Vol. 1, No. 5).

Simbolon, D., Silvia, S., \& Wahyuningrum, P. I. (2013). The Prediction of Thermal Front and Upwelling as Indicator of Potential Fishing Grounds in Mentawai Water. Marine Fisheries, $4(1), 85-95$.

Suwargana, N., \& Arief, M. (2010). Penentuan Suhu Permukaan Laut dan Konsentrasi Klorofil untuk Pengembangan Model Prediksi SST/Fishing Ground dengan Menggunakan Data MODIS. Jurnal Penginderaan Jauh dan Pengolahan Data Citra Digital, 1(1).

Utami, D. P., \& Gumilar, I. (2012). Analisis Bioekonomi Penangkapan Ikan Layur (Trichirus sp.) di Perairan Parigi Kabupaten Ciamis. Jurnal Perikanan Kelautan, 3(3).

Walton, C. C. (1988). Nonlinear multichannel algorithms for estimating sea surface temperature with AVHRR satellite data. Journal of Applied Meteorology and Climatology, 27(2), 115-124.

Wibisana, H., Sukojo, B. M., \& Lasminto, U. (2018). Penentuan Model Matematis Yang Optimal Suhu Permukaan Laut Di Pantai Utara Gresik Berbasis Nilai Reflektan Citra Satelit Aqua Modis. Geomatika, 24(1), 31-38.

Yulius, M. R., Salim, H. L., Suryono, D. D., Purbani, D., \& Heriati, A. (2015). Kualitas Air di Perairan Teluk Saleh, Kabupaten Sumbawa Berdasarkan Baku Mutu Lingkungan Hidup. Ekonomi Biru Sumberdaya Pesisir, 79. 